\title{
Effect of common antinutritive factors and fibrous feedstuffs in pig diets on amino acid digestibilities with special emphasis on threonine ${ }^{1,2}$
}

\author{
S. B. Myrie, ${ }^{*}$ R. F. Bertolo, $\dagger$ W. C. Sauer, ${ }^{* 3}$ and R. O. Ball ${ }^{* 4}$ \\ *Department of Agricultural, Food and Nutritional Science, University of Alberta, Edmonton, Alberta, Canada, \\ T6G 2P5; and †Department of Biochemistry, Memorial University of Newfoundland, \\ St. John's, Newfoundland, Canada, A1B 3X9
}

\begin{abstract}
Most feedstuffs contain antinutritive factors (ANF) such as insoluble fibers, lignins, tannins, and lectins. Intake of these ANF has the ability to reduce nutrient digestibility and to increase endogenous protein losses, such as through increased intestinal mucus secretion. The objective of this experiment was to determine the apparent ileal digestibilities (AID) of AA of $6 \mathrm{ANF}$-enriched diets to estimate endogenous protein loss associated with these ingredients in diets for young pigs. Forty-two 10-kg BW pigs fitted with a simple Tcannula at the distal ileum were randomly assigned to 1 of 7 casein-based diets with: no supplement (control), $100 \mathrm{~g} / \mathrm{kg}$ of canola meal (CM), $100 \mathrm{~g} / \mathrm{kg}$ of wheat bran (WB), $150 \mathrm{~g} / \mathrm{kg}$ of barley (BR), $22.5 \mathrm{~g} / \mathrm{kg}$ of lignin (LG), $15 \mathrm{~g} / \mathrm{kg}$ of kidney beans [as a lectin (LE) source], and $15 \mathrm{~g} / \mathrm{kg}$ of tannins (TN). All diets were formulated to be similar in $\mathrm{N}$, indispensable $\mathrm{AA}$, and caloric contents.
\end{abstract}

After a 7-d adaptation to the test diets, $\mathrm{N}$ balance was conducted for $5 \mathrm{~d}$, followed by $24 \mathrm{~h}$ of collection of digesta for analyses of AA. Pigs fed BR had 17\% lower ADG and 15\% lower feed conversion ratio $(P<0.05)$ compared with control and $\mathrm{CM}$ pigs. Pigs fed diets containing $\mathrm{WB}$ and $\mathrm{BR}$ had lower $\mathrm{N}$ retention as a percentage of absorbed $\mathrm{N}$ compared with all other groups $(P=0.03)$. The AID for CP was lower in BR, WB, and LE pigs compared with control. Of the AA, AID of Thr was notably lowest in $\mathrm{BR}, \mathrm{WB}$, and TN pigs $(P<0.05)$. The standardized ileal digestibility was lower in WB and $\mathrm{BR}$ pigs for most indispensable AA. Altogether, these data suggest that hemicellulose fiber, at concentrations typical in commercial swine diets, reduces AID of AA by increasing endogenous losses. Understanding the differential effects of ANF on endogenous losses of individual dietary AA will improve the accuracy of diet formulation.

Key words: amino acid digestibility, antinutritional factor, fiber, nitrogen balance, pig, threonine

(C2008 American Society of Animal Science. All rights reserved.

J. Anim. Sci. 2008. 86:609-619

doi:10.2527/jas.2006-793

\section{INTRODUCTION}

Cereal grains are the primary ingredients in most swine diets in western Canada and supply 30 to $60 \%$ of the total AA requirements. Because AA are an expen-

\footnotetext{
${ }^{1}$ Reported in part at the 9 th International Symposium on Digestive Physiology in Pigs, May 2003, Banff, Canada (S. B. Myrie, R. F. P. Bertolo, W. C. Sauer, and R. O. Ball. 2003. Threonine retention is reduced in diets that increase mucin production in pigs. Proceedings of the 9th International Symposium on Digestive Physiology in Pigs. Volume 2: Short Communications. University of Alberta, Edmonton, Alberta, Canada, pp. 250-252) and at Experimental Biology, April 2002, New Orleans, Louisiana [S. B. Myrie, R. F. P. Bertolo, W. C. Sauer, and R. O. Ball. 2002. Will anti-nutritive factors in foods stimulate increased intestine mucosal secretion and increase threonine requirement? FASEB J. 16:214.15 (Abstr.)].

${ }^{2}$ Supported by funds from Alberta Agricultural Research Institute (Edmonton, Alberta, Canada), Alberta Pork (Edmonton, Alberta, Canada), and Degussa AG (Düsseldorf, Germany). Amino acids donated by Degussa AG.
}

sive component of pig diets, there have been extensive studies to determine AA digestibility (Sauer et al., 2001) and true availability values in many feedstuffs (Moughan, 2003; Moehn et al., 2005). In particular, much research has attempted to improve availability estimates by correcting AA digestibility estimates for endogenous AA contributions. At present, digestibility values are corrected for endogenous losses using an estimated value, which is used to represent endogenous losses for all feedstuffs (NRC, 1998). However, the variable antinutritional factor (ANF) contents of feedstuffs are known to affect intestinal mucus secretion and may affect endogenous AA losses. For example, mucin secre-

\footnotetext{
${ }^{3}$ Current address: Instituto de Ciencias Agricolas, Universidad Autonoma de Baja California, Mexicali, Mexico 21100.

${ }^{4}$ Corresponding author: ron.ball@ualberta.ca

Received December 4, 2006.

Accepted November 2, 2007.
} 
tion is affected by dietary components (Satchithanandam et al., 1990), and its synthesis is correlated to Thr intake (Bertolo et al., 1998), because this indispensable AA is critical to the structure and function of mucin proteins (Lamont, 1992). Because gastrointestinal mucin proteins present in mucus are particularly resistant to digestion and recycling (Allen et al., 1984), an increase in mucus secretion directly leads to increased endogenous losses of AA found in mucins. Gastrointestinal mucin entering the large intestine is associated with a net loss of 20 to $30 \%$ of the AA in pigs, with the greatest amounts of AA losses being Thr, Ser, and Pro (Lien 1995).

Therefore, we hypothesized that dietary factors and ingredients that increase mucin losses will result in a greater increase in endogenous Thr losses relative to other indispensable AA. The objective of this study was to determine the effect of common ANF on the ileal recoveries of $\mathrm{CP}$ and $\mathrm{AA}$, particularly Thr.

\section{MATERIALS AND METHODS}

\section{Animals, Housing, and Surgery}

Protocols and procedures for this study were approved by the Animal Policy and Welfare Committee of the Faculty of Agriculture, Forestry and Home Economics at the University of Alberta.

Forty-eight barrows (Duroc $\times$ Yorkshire) were obtained from the University of Alberta Swine Research and Technology Center at $21 \mathrm{~d}$ of age ( 6 to $7 \mathrm{~kg}$ ). Young pigs were used, because their small intestine is more sensitive to mucus-stimulating ANF (Huisman and Tolman, 1992). On arrival, the pigs were fed a commercial starter diet (Consultant Feeds, Calmar, Alberta, Canada) for $3 \mathrm{~d}$ before surgery. After a 12-h fast, the pigs were surgically fitted with a simple T-cannula at the distal ileum, as described by Sauer (1976) and Li et al. (1993). Cannulas were approximately $3 \mathrm{~mm}$ in wall thickness, with a 13-mm internal barrel diameter; wings were $16 \mathrm{~mm}$ in diameter and $40 \mathrm{~mm}$ in length. Pigs recovered from anesthesia within 2 to $3 \mathrm{~h}$ after surgery and were fasted for an additional $24 \mathrm{~h}$ to ensure complete healing of the intestinal tissue. Pigs were housed individually in metabolic crates $(1.5 \times 1.0 \mathrm{~m})$ in a temperature-controlled room.

The next day, pigs were provided with $25 \mathrm{~g}$ of the starter diet 4 times daily at 6 -h intervals. The daily dietary allowance was gradually increased until the pigs consumed the diet at a rate of $5 \%$ of their BW (within $7 \mathrm{~d}$ ), at which time pigs were fed twice daily. During the recuperation period, the crate temperature was maintained at 30 to $32^{\circ} \mathrm{C}$ by adjusting the positioning of the infrared heating lamp. On d 1 to 3 after surgery, analgesic (Torbugesic, $0.05 \mathrm{~mL} / \mathrm{kg}$ of BW, Wyeth Animal Health Canada, Guelph, Ontario, Canada) was administered i.m. From d 3 postsurgery onwards, the animals were washed with warm water twice daily around the cannula area, and zinc oxide cream (Coopers
Agropharm Inc., Ajax, Ontario, Canada) was applied under and around the retaining ring to minimize skin irritation.

\section{Diet Regimen}

The pigs consumed the starter diet for a total of 12 d. Forty-two pigs were selected based on consistent feed intake and were adapted to the casein diet for $3 \mathrm{~d}$. Pigs (BW $9.42 \mathrm{~kg}, \mathrm{SD}=0.14$ ) were allocated randomly to either the casein-cornstarch-sugar diet (control) or 1 of 6 test diets, according to a completely randomized design. Test diets were casein-based plus: $100 \mathrm{~g} / \mathrm{kg}$ of canola meal (CM), $100 \mathrm{~g} / \mathrm{kg}$ of wheat bran (WB), $150 \mathrm{~g} /$ $\mathrm{kg}$ of barley (BR), $22.5 \mathrm{~g} / \mathrm{kg}$ of lignin (LG), $15 \mathrm{~g} / \mathrm{kg}$ of kidney beans [as a lectin (LE) source], and $15 \mathrm{~g} / \mathrm{kg}$ of tannins (TN; Table 1). The aim was to supplement the diets with these ingredients at levels that include ANF at concentrations that are commonly present in practical pig diets. For example, the level of lectins found in typical pig diets containing various feedstuffs (Nachbar and Oppenheim, 1980) is approximately $3.0 \mathrm{~g} / \mathrm{kg}$. Relative to other beans and legumes, the lectins in kidney beans have been shown to be the most potent of antinutritional factors in these beans (Pusztai et al., 1982; Bond and Smith, 1989); $15 \mathrm{~g}$ of red kidney beans provided $3.0 \mathrm{~g}$ of lectins $/ \mathrm{kg}$ to the diet. Barley, sorghum, rapeseed, and millet are particularly rich in tannins, and a typical intake of $20 \mathrm{~g}$ of dietary tannins $/ \mathrm{kg}$ was estimated for pig diets (Bravo, 1998). Because cellulose as a dietary fiber source has been shown to have no effect on ileal endogenous $\mathrm{N}$ excretion in pigs (de Lange et al., 1989; Furuya and Kaji, 1992; Leterme et al., 1992), the fibrous constituents other than cellulose in purified NDF (i.e., hemicellulose and lignin) induce the increased endogenous $\mathrm{N}$ secretion. After cellulose, lignins are the second most abundant fiber component in most plants and can also be used as a binding agent during pelleting. Because lignin levels of 30 to $60 \mathrm{~g} / \mathrm{kg}$ are present in most plant food sources (Shah et al., 1982; Chiou et al., 1994), we chose an inclusion level of $22.5 \mathrm{~g} / \mathrm{kg}$ to reflect a cereal-based pig diet. High, moderate, and low hemicellulose diets were also included to assess the effect of hemicellulose level on endogenous $\mathrm{N}$ secretion. Wheat bran was used at an inclusion level of $100 \mathrm{~g} / \mathrm{kg}$ to reflect a $300 \mathrm{~g} / \mathrm{kg}$ wheat diet to represent a high hemicellulose concentration (Table 1). Lastly, barley and canola meal are the primary feedstuffs fed to swine in western Canada, so we included $150 \mathrm{~g} / \mathrm{kg}$ of barley and $100 \mathrm{~g} / \mathrm{kg}$ of canola meal diets to reflect moderate and low hemicellulose concentrations, respectively. We equalized total dietary cellulose in all diets in an effort to isolate the effects of hemicellulose in these 3 diets (Table 1).

All diets were formulated to meet or exceed intake of all nutrients according to the NRC (1998), which included additions of Cys, Thr, and Trp to all diets. In particular, the indispensable AA concentrations were matched as closely as possible, accounting for the pro- 
Table 1. Ingredients and calculated composition of the experimental diets, as-fed basis

\begin{tabular}{|c|c|c|c|c|c|c|c|}
\hline \multirow[b]{2}{*}{ Item } & \multicolumn{7}{|c|}{ Test diets } \\
\hline & Control & $\begin{array}{c}\text { Canola } \\
\text { meal }\end{array}$ & $\begin{array}{c}\text { Wheat } \\
\text { bran }\end{array}$ & Barley & Lignin & Lectin & Tannins \\
\hline \multicolumn{8}{|l|}{ Ingredients, $\mathrm{g} / \mathrm{kg}$} \\
\hline Barley $^{1}$ & - & - & - & 150.0 & - & - & - \\
\hline Canola meal $^{1}$ & - & 100.0 & - & - & - & - & - \\
\hline Casein & 145.0 & 123.0 & 140.0 & 140.0 & 145.0 & 142.0 & 145.0 \\
\hline Chromic oxide ${ }^{2}$ & 5.0 & 5.0 & 5.0 & 5.0 & 5.0 & 5.0 & 5.0 \\
\hline Corn oil & 4.0 & 22.5 & 34.0 & 38.0 & 24.0 & 2.0 & 17.5 \\
\hline Cornstarch & 380.0 & 312.7 & 274.6 & 212.6 & 338.3 & 376.0 & 352.3 \\
\hline Dicalcium phosphate & 15.0 & 15.0 & 15.0 & 15.0 & 15.0 & 15.0 & 15.0 \\
\hline Kidney beans ${ }^{3}$ & - & - & - & - & - & 15.0 & - \\
\hline $\mathrm{L}-\mathrm{Asn}^{4}$ & 48.0 & 40.0 & 44.0 & 44.0 & 48.0 & 48.0 & 48.0 \\
\hline L-Cys & 2.8 & 2.1 & 2.5 & 2.5 & 2.8 & 2.8 & 2.8 \\
\hline $\operatorname{Lignin}^{5}$ & - & - & - & - & 22.5 & - & - \\
\hline Limestone & 10.0 & 10.0 & 10.0 & 10.0 & 10.0 & 10.0 & 10.0 \\
\hline L-Thr & 0.9 & 0.5 & 0.7 & 0.7 & 0.9 & 0.9 & 0.9 \\
\hline L-Trp & 0.3 & 0.2 & 0.2 & 0.2 & 0.3 & 0.3 & 0.3 \\
\hline Mg sulfate & 2.0 & - & - & 2.0 & 2.0 & 2.0 & 2.0 \\
\hline $\mathrm{K}$ chloride & 5.3 & 3.0 & 3.0 & 4.0 & 5.3 & 5.0 & 5.3 \\
\hline Na bicarbonate & 6.0 & 6.0 & 6.0 & 6.0 & 6.0 & 6.0 & 6.0 \\
\hline Solkafloc ${ }^{6}$ & $\begin{array}{r}0.0 \\
15.0\end{array}$ & - & 5.0 & $\begin{array}{r}0.0 \\
10.0\end{array}$ & $\begin{array}{r}0.0 \\
15.0\end{array}$ & $\begin{array}{r}0.0 \\
10.0\end{array}$ & 15.0 \\
\hline Sugar (sucrose) ${ }^{7}$ & 350.0 & 350.0 & 350.0 & 350.0 & 350.0 & 350.0 & 350.0 \\
\hline Tannins ${ }^{8}$ & - & - & - & - & - & - & 15.0 \\
\hline Vitamin-mineral $\operatorname{mix}^{9}$ & 10.0 & 10.0 & 10.0 & 10.0 & 10.0 & 10.0 & 10.0 \\
\hline Wheat bran ${ }^{7}$ & - & - & 100.0 & - & - & - & - \\
\hline Total & $1,000.0$ & $1,000.0$ & $1,000.0$ & $1,000.0$ & $1,000.0$ & $1,000.0$ & $1,000.0$ \\
\hline \multicolumn{8}{|l|}{ Calculated composition } \\
\hline $\mathrm{ME}, \mathrm{kcal} / \mathrm{kg}$ & 3,621 & 3,628 & 3,626 & 3,626 & 3,621 & 3,621 & 3,621 \\
\hline $\mathrm{CP}, \%$ & 19.63 & 20.07 & 20.15 & 20.14 & 19.62 & 19.70 & 19.62 \\
\hline $\mathrm{NDF},{ }^{10} \mathrm{~g} / \mathrm{kg}$ & - & 21.2 & 42.1 & 27.9 & 22.5 & 10.6 & - \\
\hline $\mathrm{ADF},{ }^{10} \mathrm{~g} / \mathrm{kg}$ & - & 17.2 & 13.0 & 10.5 & 22.5 & 5.6 & - \\
\hline Hemicellulose, ${ }^{10} \mathrm{~g} / \mathrm{kg}$ & - & $\begin{array}{r}1 . .4 \\
4.0\end{array}$ & 29.1 & 17.4 & - & 5.0 & - \\
\hline Lignin, ${ }^{10} \mathrm{~g} / \mathrm{kg}$ & - & 2.0 & 2.5 & 5.0 & 22.5 & 0.4 & - \\
\hline Cellulose,${ }^{10} \mathrm{~g} / \mathrm{kg}$ & - & 15.2 & 10.5 & 5.5 & - & 5.2 & - \\
\hline Total cellulose ${ }^{11} \mathrm{~g} / \mathrm{kg}$ & 15.0 & 15.2 & 15.5 & 15.5 & 15.0 & 15.2 & 15.0 \\
\hline
\end{tabular}

${ }^{1}$ Barley and canola meal were obtained from the University of Alberta feed mill.

${ }^{2}$ Fisher Scientific (Fair Lawn, NJ).

${ }^{3}$ Kidney beans were used as a source of lectins (Unico Inc., Concord, Ontario, Canada); this inclusion level provided approximately $3.0 \mathrm{~g}$ of lectins/kg for the total diet (Nachbar and Oppenheim, 1980; Pusztai et al., 1982).

${ }^{4} \mathrm{~L}$-Asparagine added to make all diets isonitrogenous.

${ }^{5}$ Lignin used was sodium lignosulfonate donated by Tembec Chemical \& Power Group Inc. (Quebec, Canada).

${ }^{6}$ Provided cellulose.

${ }^{7}$ Sugar and wheat bran were from Rogers Foods Ltd. (Armstrong, British Columbia, Canada).

${ }^{8}$ Grape tannins were used as a source of tannins (Prescott \& Co., Mississauga, Ontario, Canada).

${ }^{9}$ Provided the following per kilogram of diet: $215 \mathrm{mg}$ of Ca, $84 \mathrm{mg}$ of digestible $\mathrm{P}, 10 \mathrm{mg}$ of $\mathrm{Mg}, 2.0 \mathrm{mg}$ of $\mathrm{S}, 6.0 \mathrm{mg}$ of $\mathrm{Cu}$ (as copper sulfate), $99 \mu \mathrm{g}$ of I (as potassium iodate), $70 \mathrm{mg}$ of $\mathrm{Fe}$ (as ferrous sulfate), 16 $\mathrm{mg}$ of $\mathrm{Mn}$ (as manganese sulfate), $74 \mu \mathrm{g}$ of Se (as sodium selenite), $35 \mathrm{mg}$ of $\mathrm{Zn}$ (as zinc carbonate), $150 \mu \mathrm{g}$ of biotin, $130 \mathrm{mg}$ of choline, $0.8 \mathrm{mg}$ of folacin, $6.2 \mathrm{mg}$ of pantothenic acid (as calcium pantothenate), $9.5 \mathrm{mg}$ of niacin, $1.75 \mathrm{mg}$ of riboflavin, $8.8 \mu \mathrm{g}$ of vitamin $\mathrm{B}_{12}, 15.5 \mathrm{mg}$ of vitamin $\mathrm{E}$ (as DL- $\alpha$-tocopheryl acetate), $3,000 \mathrm{IU}$ of vitamin $\mathrm{A}$ (as vitamin A acetate), and $350 \mathrm{IU}$ of vitamin $\mathrm{D}_{3}$.

${ }^{10} \mathrm{NDF}=\mathrm{ADF}+$ hemicellulose; $\mathrm{ADF}=$ cellulose + lignin; hemicellulose $=\mathrm{NDF}-\mathrm{ADF} ;$ cellulose $=\mathrm{ADF}-$ lignin.

${ }^{11}$ Total cellulose $=$ calculated cellulose + added Solkafloc.

tein contribution and digestibility of the barley and canola meal test ingredients. Diets were designed with Thr as the first-limiting AA (at 100\% of the requirement), with other indispensable AA set to at least $105 \%$ of the requirements across diets (NRC, 1998). Analyzed chemical and AA compositions of the experimental diets are presented in Table 2 . The analyzed values of CP and AA in the experimental diets were very close to the calculated values used to formulate the diets. Chromic oxide was included in the diets at a rate of $0.5 \%$ as an indigestible marker. Feed intake was restricted to 5\% of BW, with the total daily feed intake of each pig divided in equal amounts and fed twice daily (at 0700 and 1900). Pigs were weighed, and feed intakes were adjusted on a daily basis. Water was provided on an ad libitum basis from a low-pressure drinking nipple. 
Table 2. Analyzed composition of the experimental diets (as-fed basis)

\begin{tabular}{|c|c|c|c|c|c|c|c|}
\hline Item & Control & $\begin{array}{c}\text { Canola } \\
\text { meal }\end{array}$ & $\begin{array}{l}\text { Wheat } \\
\text { bran }\end{array}$ & Barley & Lignin & Lectin & Tannins \\
\hline $\mathrm{OM}, \%$ & 95.60 & 95.22 & 95.32 & 95.47 & 95.02 & 95.78 & 95.79 \\
\hline $\mathrm{CP},{ }^{1} \%$ & 17.80 & 18.96 & 18.06 & 19.27 & 18.30 & 18.08 & 17.81 \\
\hline DM, \% & 94.65 & 94.94 & 94.70 & 94.71 & 94.83 & 94.65 & 94.52 \\
\hline Ether extract, \% & 0.19 & 1.89 & 2.85 & 2.75 & 1.79 & 0.12 & 1.13 \\
\hline $\mathrm{ME},{ }^{1} \mathrm{kcal} / \mathrm{kg}$ & 3,578 & 3,540 & 3,187 & 3,730 & 3,097 & 3,551 & 3,454 \\
\hline \multicolumn{8}{|c|}{ Indispensable AA, \% } \\
\hline Arg & 0.36 & 0.51 & 0.45 & 0.44 & 0.36 & 0.37 & 0.36 \\
\hline His & 0.32 & 0.36 & 0.34 & 0.34 & 0.32 & 0.32 & 0.32 \\
\hline Ile & 0.63 & 0.66 & 0.65 & 0.67 & 0.63 & 0.63 & 0.63 \\
\hline Leu & 1.12 & 1.24 & 1.22 & 1.28 & 1.18 & 1.18 & 1.18 \\
\hline Lys & 0.92 & 0.96 & 0.94 & 0.95 & 0.92 & 0.92 & 0.92 \\
\hline Met & 0.38 & 0.39 & 0.39 & 0.40 & 0.38 & 0.38 & 0.38 \\
\hline Phe & 0.61 & 0.66 & 0.65 & 0.69 & 0.61 & 0.62 & 0.61 \\
\hline Thr & 0.64 & 0.67 & 0.65 & 0.67 & 0.64 & 0.64 & 0.64 \\
\hline Trp & 0.20 & 0.21 & 0.21 & 0.21 & 0.20 & 0.20 & 0.20 \\
\hline Val & 0.78 & 0.83 & 0.81 & 0.84 & 0.78 & 0.78 & 0.78 \\
\hline \multicolumn{8}{|l|}{ Dispensable AA, \% } \\
\hline Ala & 0.36 & 0.46 & 0.41 & 0.42 & 0.36 & 0.36 & 0.36 \\
\hline Asp & 0.85 & 0.97 & 0.92 & 0.93 & 0.85 & 0.87 & 0.85 \\
\hline Cys & 0.10 & 0.16 & 0.13 & 0.14 & 0.10 & 0.10 & 0.10 \\
\hline Glu & 2.68 & 2.87 & 2.86 & 3.07 & 2.68 & 2.68 & 2.68 \\
\hline Gly & 0.22 & 0.36 & 0.29 & 0.29 & 0.22 & 0.23 & 0.22 \\
\hline Pro & 1.34 & 1.35 & 1.39 & 1.50 & 1.34 & 1.33 & 1.34 \\
\hline Ser & 0.66 & 0.71 & 0.70 & 0.72 & 0.66 & 0.67 & 0.66 \\
\hline
\end{tabular}

${ }^{1}$ Crude protein calculated as total $\mathrm{N} \times 6.25$; $\mathrm{ME}$ calculated from the $\mathrm{DE}$ and $\mathrm{CP}$ of the diet. The average of the following 3 equations was used to determine ME: ME $=\mathrm{DE}(1.012-(0.0019 \times \% \mathrm{CP})$ (May and Bell, 1971); $\mathrm{ME}=\mathrm{DE}[0.988-(0.002 \times \% \mathrm{CP})]($ Noblet et al., 1989); and ME = DE [1.003-(0.0021 $\% \% \mathrm{CP})]($ Noblet and Perez, 1993).

\section{Conduct of the Study}

After $7 \mathrm{~d}$ of recovery from surgery, the pigs were given $3 \mathrm{~d}$ of adaptation to the casein diet. The experimental diets were then fed for $7 \mathrm{~d}$, followed by total urine and feces collection for $5 \mathrm{~d}$, from 0700 on d 6 until 0700 on $\mathrm{d} 11$ of each experimental period. Concentrated $(18.4 M$ ) sulfuric acid was added (5 to $8 \mathrm{~mL}$ ) to each urine flask to prevent $\mathrm{NH}_{3}$ loss. After collection, the volume of urine was measured, and aliquots of urine and feces were frozen at $-20^{\circ} \mathrm{C}$ to determine total $\mathrm{N}$ output. After the $\mathrm{N}$ balance study, ileal digesta were collected for a total of $24 \mathrm{~h}$, from 0600 to 1800 on d 11 and from 1800 on $\mathrm{d} 12$ to 0600 on $\mathrm{d} 13$ of each experimental period, and stored at $-20^{\circ} \mathrm{C}$ until analyzed. The digesta were freeze-dried, pooled within pig, and mixed before analyses.

After the ileal digesta collection period, the pigs were sedated using a mixture of halothane and $\mathrm{O}_{2}$. Twenty milliliters of blood was obtained from the heart via needle puncture and then transferred into heparinized tubes and centrifuged, and plasma samples were collected and frozen at $-80^{\circ} \mathrm{C}$ until AA analyses. Pigs were then slaughtered.

\section{Analytical Procedures}

Diets, feces, and freeze-dried digesta were analyzed for DM according to the AOAC (1995) and for N using the method described by Sweeney and Rexroad (1987). Nitrogen contents of urine samples were determined by Kjeldahl analysis (Bradstreet, 1965). Amino acid contents of the diets were determined by Degussa AG, Düsseldorf, Germany (Llames and Fontaine, 1994), and in ileal digesta by HPLC after acid hydrolysis in $6 \mathrm{~N} \mathrm{HCl}$ for $24 \mathrm{~h}$ (Sedgwick et al., 1991). Chromium analyses on feed, digesta, and fecal samples were performed by the method of Fenton and Fenton (1979).

The apparent digestibility of components in ileal digesta were determined by the following equation: apparent ileal digestibilities (AID), $\%=\left[1-\left(\mathrm{N}_{\mathrm{D}} \times \mathrm{Cr}_{\mathrm{F}}\right) /\right.$ $\left.\left(\mathrm{N}_{\mathrm{F}} \times \mathrm{Cr}_{\mathrm{D}}\right)\right] \times 100 \%$, where $\mathrm{N}_{\mathrm{D}}=$ the concentration of the component in ileal digesta; $\mathrm{Cr}_{\mathrm{F}}=$ the concentration of $\mathrm{Cr}$ in feed; $\mathrm{N}_{\mathrm{F}}=$ concentration of the component in the diet; and $\mathrm{Cr}_{\mathrm{D}}=$ the concentration of $\mathrm{Cr}$ in ileal digesta. The flow of a component through the distal ileum was calculated based on the $\mathrm{Cr}$ in the diet and the equation described by Furuya and Kaji (1992), where ileal flow of a component $(\mathrm{g} / \mathrm{d})=[$ concentration of a component in ileal digesta, $\mathrm{g} / \mathrm{g}) \times$ (concentration of $\mathrm{Cr}$ in the diet, g/g)/concentration of $\mathrm{Cr}$ in ileal digesta $(\mathrm{g} / \mathrm{g})] \times$ feed intake of component $(\mathrm{g} / \mathrm{d})$.

All diets in this experiment were casein-based; as such, the casein-cornstarch-sucrose diet was used as the basal diet to estimate endogenous protein and AA losses. Endogenous component losses (ECL) were calculated from the equation provided by Moughan and 
Table 3. Apparent ileal digestibility (\%) of $\mathrm{CP}$ and AA in growing pigs fed diets containing common levels of antinutritional factors ${ }^{1}$

\begin{tabular}{|c|c|c|c|c|c|c|c|c|c|}
\hline Item & Control & $\begin{array}{c}\text { Canola } \\
\text { meal }\end{array}$ & $\begin{array}{l}\text { Wheat } \\
\text { bran }\end{array}$ & Barley & Lignin & Lectin & Tannins & $\mathrm{SD}$ & $\begin{array}{c}P- \\
\text { value }\end{array}$ \\
\hline $\mathrm{CP}, \%$ & $91.9^{\mathrm{a}}$ & $87.2^{\mathrm{ab}}$ & $83.2^{\mathrm{b}}$ & $85.1^{\mathrm{b}}$ & $91.5^{\mathrm{a}}$ & $85.3^{\mathrm{b}}$ & $87.2^{\mathrm{ab}}$ & 7.0 & 0.01 \\
\hline \multicolumn{10}{|l|}{ Indispensable AA, \% } \\
\hline Arg & 93.2 & 90.1 & 82.1 & 83.9 & 91.8 & 83.8 & 79.8 & 2.0 & 0.06 \\
\hline $\mathrm{His}$ & 96.1 & 92.8 & 87.1 & 90.3 & 95.4 & 91.0 & 86.7 & 1.4 & 0.08 \\
\hline Ile & $94.7^{\mathrm{a}}$ & $91.2^{\mathrm{ab}}$ & $86.9^{\mathrm{b}}$ & $87.9^{\mathrm{b}}$ & $94.9^{\mathrm{a}}$ & $90.6^{\mathrm{ab}}$ & $89.3^{\mathrm{b}}$ & 2.0 & 0.02 \\
\hline Leu & 95.5 & 91.9 & 86.3 & 88.4 & 96.2 & 93.0 & 90.7 & 2.1 & 0.06 \\
\hline Lys & 96.0 & 91.8 & 86.1 & 89.4 & 96.2 & 92.6 & 90.7 & 1.7 & 0.07 \\
\hline Phe & 96.0 & 92.6 & 87.7 & 89.1 & 95.8 & 91.3 & 90.9 & 2.0 & 0.07 \\
\hline Thr & $90.6^{\mathrm{a}}$ & $85.5^{\mathrm{abc}}$ & $80.9^{c}$ & $80.2^{\mathrm{c}}$ & $89.3^{\mathrm{ab}}$ & $83.7^{\mathrm{abc}}$ & $82.6^{\mathrm{bc}}$ & 2.4 & 0.05 \\
\hline Val & $93.3^{\mathrm{a}}$ & $87.6^{\mathrm{abc}}$ & $81.1^{\mathrm{c}}$ & $84.3^{\mathrm{bc}}$ & $95.0^{\mathrm{a}}$ & $91.0^{\mathrm{ab}}$ & $87.1^{\mathrm{abc}}$ & 3.0 & 0.02 \\
\hline \multicolumn{10}{|l|}{ Dispensable AA, \% } \\
\hline $\mathrm{Ala}$ & $88.5^{\mathrm{a}}$ & $85.5^{\mathrm{ab}}$ & $70.3^{\mathrm{c}}$ & $74.6^{\mathrm{bc}}$ & $88.5^{\mathrm{a}}$ & $80.0^{\mathrm{abc}}$ & $76.2^{\mathrm{abc}}$ & 3.7 & 0.04 \\
\hline Asp & 85.5 & 84.6 & 79.2 & 79.0 & 90.7 & 84.1 & 75.3 & 9.9 & 0.72 \\
\hline Glu & 95.0 & 93.4 & 91.0 & 88.7 & 94.8 & 92.5 & 89.5 & 2.3 & 0.21 \\
\hline Gly & 79.0 & 75.7 & 62.7 & 67.1 & 76.3 & 61.9 & 52.4 & 4.1 & 0.09 \\
\hline Ser & 91.2 & 88.4 & 84.5 & 83.4 & 90.4 & 84.3 & 85.7 & 1.9 & 0.11 \\
\hline Tyr & $97.1^{\mathrm{a}}$ & $94.2^{\mathrm{ab}}$ & $90.7^{\mathrm{b}}$ & $91.0^{\mathrm{b}}$ & $96.5^{\mathrm{a}}$ & $93.1^{\mathrm{ab}}$ & $92.7^{\mathrm{ab}}$ & 2.0 & 0.05 \\
\hline
\end{tabular}

Schuttert (1991), ECL $=\mathrm{N}_{\mathrm{D}} \times\left(\mathrm{Cr}_{\mathrm{F}} / \mathrm{Cr}_{\mathrm{D}}\right)$, where $\mathrm{N}_{\mathrm{D}}=$ the concentration of a component in ileal digesta and $\mathrm{Cr}_{\mathrm{F}}$ and $\mathrm{Cr}_{\mathrm{D}}=$ the concentration of $\mathrm{Cr}$ in feed and digesta, respectively. Standardized ileal digestibility (SID) was determined from the equation of Smiricky et al. (2002), where SID = apparent digestibility + $\left[\left(\mathrm{ECL} / \mathrm{N}_{\mathrm{D}}\right) \times 100\right]$.

\section{Statistical Analyses}

The experiment used a complete randomized design using the GLM procedure (SAS Inst. Inc., Cary, NC). Differences among diets for ADG, $\mathrm{N}$ balance, mucin output, and digesta AA concentrations were assessed by protected LSD multiple-comparisons procedure and were considered statistically significant at $P<0.05$. An analysis of covariance, using initial BW as the covariate, was tested against BW gain and was not significant.

\section{RESULTS}

\section{Growth Performance}

The pigs remained healthy and attentive to their environment throughout the trial. Postmortem examinations of the pigs revealed no adhesions or other intestinal abnormalities due to cannulation. The BW of the pigs at the start $(9.42 \mathrm{~kg}, \mathrm{SD}=0.14)$ and end of the experiment $(15.41 \mathrm{~kg}, \mathrm{SD}=0.77)$ were not different among diets. All pigs consumed their entire feed ration throughout the trial, so the ADFI of the pigs was not different among diets $(0.57 \mathrm{~kg}, \mathrm{SD}=0.06)$ but $\mathrm{ADG}$ was decreased $(P<0.05)$ for pigs receiving WB $(0.31 \mathrm{~kg} / \mathrm{d})$ compared with control, CM, and TN diets (all at 0.41 $\mathrm{kg} / \mathrm{d})$.

\section{Ileal AA and Protein Digestibility}

The AID of CP and AA for the control diet (Table 3) were in close agreement with results reported by other researchers (Kies et al., 1986; Furuya and Kaji, 1989; Chung and Baker, 1992). Of particular note, the AID of $\mathrm{CP}$ was decreased for $\mathrm{WB}, \mathrm{BR}$, and $\mathrm{LE}$ diets relative to control $(P=0.01)$, and AID of Thr, Val, Ile, Ala, and Tyr were decreased for $\mathrm{WB}$ and $\mathrm{BR}$ diets relative to control $(P<0.05$; Table 3$)$; AID of Thr and Ile were also decreased compared with control in TN diets $(P<0.05)$. Overall, AID of all indispensable AA tended to be decreased in $\mathrm{WB}$ and $\mathrm{BR}$ pigs $(P<0.08)$. Comparing endogenous losses among ANF groups, SID of most indispensable AA were decreased in WB, BR, and TN groups compared with other ANF groups $(P<0.05)$; however, SID for Thr and His were not different $(P<0.12$; Table 4). On average, SID values for AA and protein were $7 \%$ greater than the AID values for all diets. Although casein concentrations varied among diets, total CP was constant, and for all ANF groups, casein contributed $>97 \%$ of total protein, except for the CM diet, where casein contributed $>85 \%$ of total CP. The effects of these slight variations of casein concentration on total endogenous losses were likely negligible. Furthermore, with respect to the protein contribution of canola meal, wheat bran, barley, and kidney beans, we used true ileal digestibility estimates of AA in these respective feedstuffs. Thus, changes in AID in this study would be attributable to changes in endogenous losses and not variations in digestibility among feedstuffs. 
Table 4. Standardized ${ }^{1}$ ileal digestibility (\%) of protein and AA in growing pigs fed diets containing common levels of antinutritional factors ${ }^{2}$

\begin{tabular}{|c|c|c|c|c|c|c|c|c|}
\hline Item & $\begin{array}{c}\text { Canola } \\
\text { meal }\end{array}$ & $\begin{array}{l}\text { Wheat } \\
\text { bran }\end{array}$ & Barley & Lignin & Lectin & Tannins & $\mathrm{SD}$ & $\begin{array}{c}P- \\
\text { value }\end{array}$ \\
\hline $\mathrm{CP}, \%$ & 93.7 & 91.6 & 92.4 & 99.6 & 91.1 & 93.8 & 7.4 & 0.27 \\
\hline \multicolumn{9}{|l|}{ Indispensable AA, \% } \\
\hline Arg & $96.4^{\mathrm{abc}}$ & $88.4^{\mathrm{dc}}$ & $89.6^{\mathrm{abcd}}$ & $99.7^{\mathrm{ab}}$ & $88.9^{\text {bcd }}$ & $84.5^{\mathrm{d}}$ & 10.4 & 0.04 \\
\hline His & 98.6 & 93.2 & 95.9 & 103.4 & 96.7 & 90.9 & 8.3 & 0.06 \\
\hline Ile & $98.1^{\mathrm{abc}}$ & $93.9^{c}$ & $94.0^{\mathrm{c}}$ & $104.2^{\mathrm{a}}$ & $97.6^{\mathrm{abc}}$ & $95.8^{\mathrm{bc}}$ & 6.3 & 0.02 \\
\hline Leu & $98.3^{\mathrm{abc}}$ & $92.8^{\mathrm{c}}$ & $93.8^{\mathrm{c}}$ & $106.5^{\mathrm{a}}$ & $100.8^{\mathrm{abc}}$ & $96.9^{\mathrm{bc}}$ & 8.0 & 0.03 \\
\hline Lys & $97.5^{\mathrm{abc}}$ & $91.9^{c}$ & $94.9^{\mathrm{bc}}$ & $105.5^{\mathrm{a}}$ & $99.7^{\mathrm{abc}}$ & $96.4^{\mathrm{bc}}$ & 7.9 & 0.04 \\
\hline Phe & $98.8^{\mathrm{abc}}$ & $94.0^{\mathrm{c}}$ & $94.1^{\mathrm{c}}$ & $104.3^{\mathrm{a}}$ & $97.1^{\mathrm{abc}}$ & $96.8^{\mathrm{bc}}$ & 6.9 & 0.04 \\
\hline Thr & 92.7 & 88.6 & 87.1 & 97.0 & 90.5 & 89.2 & 7.8 & 0.12 \\
\hline Val & $93.9^{\mathrm{bc}}$ & $87.7^{\mathrm{c}}$ & $90.4^{\mathrm{c}}$ & $106.9^{\mathrm{a}}$ & $100.5^{\mathrm{ab}}$ & $93.7^{\mathrm{bc}}$ & 9.7 & 0.003 \\
\hline \multicolumn{9}{|l|}{ Dispensable AA, \% } \\
\hline Ala & $92.8^{\mathrm{abc}}$ & $76.5^{\mathrm{d}}$ & $80.5^{\mathrm{dc}}$ & $97.6^{\mathrm{a}}$ & $87.1^{\text {abcd }}$ & $82.6^{\mathrm{bcd}}$ & 13.1 & 0.02 \\
\hline Asp & 91.9 & 89.9 & 87.3 & 101.6 & 92.5 & 82.0 & 15.0 & 0.49 \\
\hline Glu & 101.2 & 100.1 & 94.6 & 104.4 & 100.3 & 95.7 & 6.8 & 0.15 \\
\hline Gly & $81.7^{\mathrm{a}}$ & $69.9^{\mathrm{ab}}$ & $73.4^{\mathrm{ab}}$ & $85.1^{\mathrm{a}}$ & $67.7^{\mathrm{ab}}$ & $58.1^{\mathrm{b}}$ & 17.8 & 0.05 \\
\hline Ser & 96.5 & 93.4 & 90.5 & 98.5 & 91.0 & 92.5 & 6.8 & 0.20 \\
\hline Tyr & $100.2^{\mathrm{ab}}$ & $96.5^{\mathrm{b}}$ & $95.7^{\mathrm{b}}$ & $104.2^{\mathrm{a}}$ & $98.6^{\mathrm{ab}}$ & $98.2^{\mathrm{ab}}$ & 5.7 & 0.04 \\
\hline
\end{tabular}

${ }^{\mathrm{a}-\mathrm{d}}$ Values with different superscripts within the same row are different at $P<0.05 ; \mathrm{n}=6$ per dietary treatment.

${ }^{1}$ Casein (control) diet was used to determine basal loss and digestibility, according to the formulations of Moughan and Schuttert (1991) and Smiricky et al. (2002).

${ }^{2}$ All diets were casein-based with: no supplement (control), $100 \mathrm{~g} / \mathrm{kg}$ of canola meal, $100 \mathrm{~g} / \mathrm{kg}$ of wheat bran, $150 \mathrm{~g} / \mathrm{kg}$ of barley, $22.5 \mathrm{~g} / \mathrm{kg}$ of lignin, $15 \mathrm{~g} / \mathrm{kg}$ of kidney beans (as a lectin source), or $15 \mathrm{~g} / \mathrm{kg}$ of tannins.

\section{Endogenous Ileal AA and Protein Losses and $N$ Balance}

Total ileal flow of protein (Figure 1), Thr (Figure 2), and Ser (Figure 3) were greatest for pigs fed the diets containing wheat bran and barley. The ileal Thr flows (mg/d) for pigs offered the WB (69.1), BR (73.5), CM (56.4), and TN (59.1) diets were all $(P=0.001)$ greater than those for pigs fed the control (37.5) and LG (36.3) diets (Figure 2). Among the diets, the ileal flow of Ser (Figure 3) followed a similar pattern as Thr. Similarly, ileal protein flows (g/d; Figure 1) for pigs offered the WB (6.90), BR (7.53), CM (5.90), and LE diets (5.64) were $(P=0.01)$ greater than for those fed the control $\operatorname{diet}(3.65)$.

During the course of the $\mathrm{N}$ balance study, $\mathrm{N}$ intake and excretion were similar among pigs given the 7 diets (Table 5). However, 2 pigs in the WB group had decreased growth rates in spite of consuming their entire feed ration; because feed intake was restricted according to BW, these pigs had lower absolute $\mathrm{N}$ intakes. When corrected for this lower intake, pigs fed diets containing $\mathrm{WB}$ and $\mathrm{BR}$ had lower $\mathrm{N}$ retention as a percentage of absorbed N ( $P=0.03$; Table 5$)$; $\mathrm{N}$ retention in grams per day and as a percentage of intake tended to be lower in the WB group $(P=0.16$ and $P=$ 0.14 , respectively).

\section{DISCUSSION}

Endogenous $\mathrm{N}$ and AA recoveries in digesta collected from the distal ileum have traditionally been determined after feeding a protein-free diet. However, this method has been criticized for creating a physiologically abnormal state (Low, 1980). Other studies (Moughan and Rutherford, 1990; Butts et al., 1993) have shown that the presence of dietary protein or peptides in the gastrointestinal tract results in increased recoveries of endogenous $\mathrm{N}$ and $\mathrm{AA}$ in ileal digesta compared with a protein-free diet. Under most conditions, it is assumed that the endogenous $\mathrm{N}$ loss (which includes mucin, along with sloughed cells, enzymes, and other intestinal secretions) is relatively constant (Furuya and Kaji, 1992). However, if a feedstuff contains components that stimulate endogenous secretions, especially mucus, then the amount of mucin, and therefore AA losses, becomes a variable function, dependent upon the dietary ingredients.

The main objective of this trial was to determine the flow of Thr in ileal digesta to measure the total losses per day regardless of source of loss (i.e., endogenous plus dietary losses). All diets were formulated to provide equal amounts of total Thr, with all other AA intakes above requirement and approximately similar among diets (Table 2). In addition, the only Thr sources in the diets were from casein and the experimental feedstuffs (Table 1). Thus, total ileal Thr loss, along with $\mathrm{N}$ balance, allows estimates of differences in endogenous Thr loss due to the different diet ingredients. Differences among feedstuffs in endogenous Thr losses have significant implications for the Thr intake necessary to meet the requirement of lean growth.

The highly digestible casein diet in this experiment was used as the basal diet to estimate endogenous protein and AA output. Diets containing highly digestible protein sources, such as casein, are commonly used to 


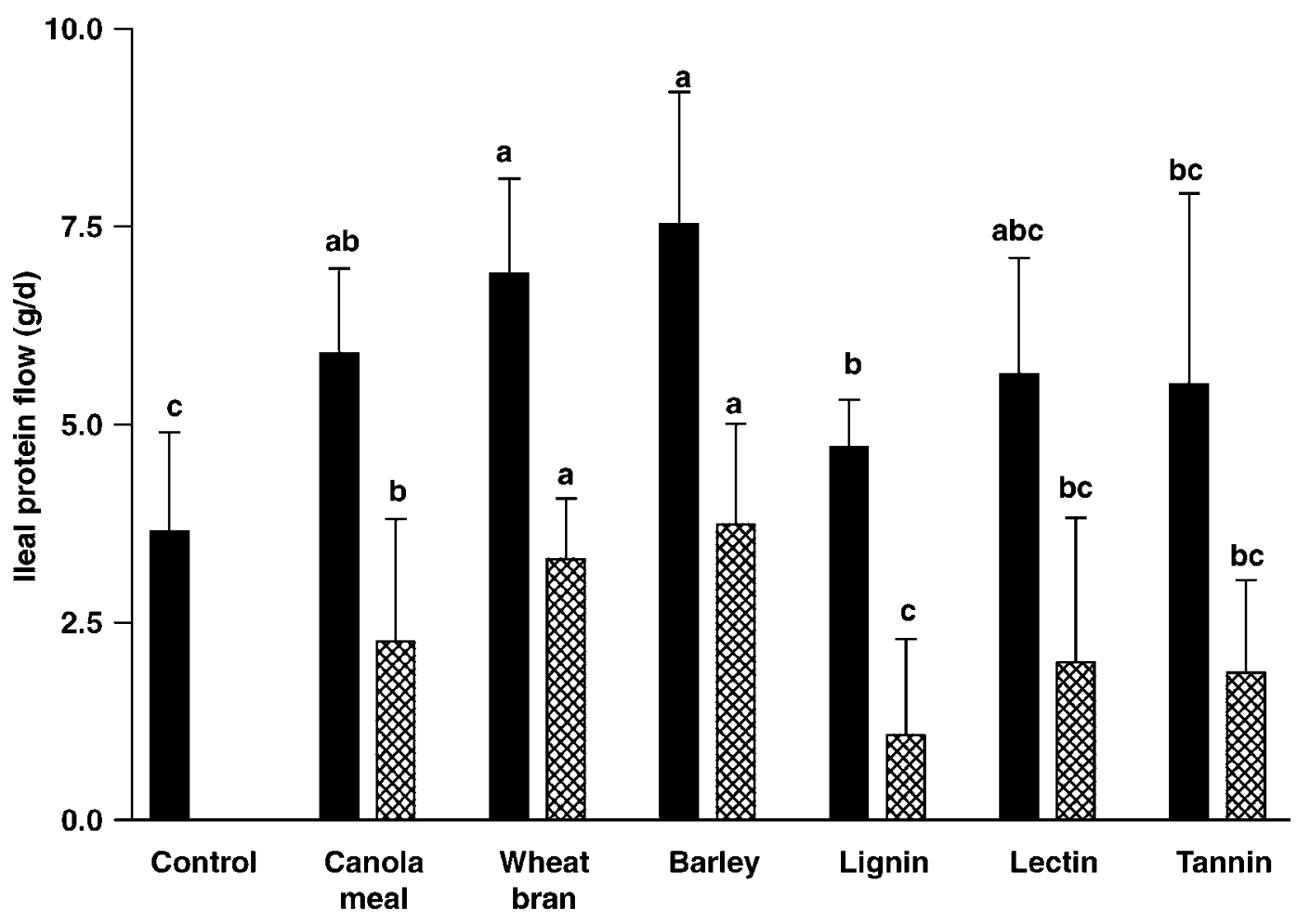

Total protein

Specific protein

Figure 1. Total and ingredient-specific ileal protein flow $(\mathrm{g} / \mathrm{d})$ in growing pigs fed casein-based diets with: no supplement (control), $100 \mathrm{~g} / \mathrm{kg}$ of canola meal, $100 \mathrm{~g} / \mathrm{kg}$ of wheat bran, $150 \mathrm{~g} / \mathrm{kg}$ of barley, $22.5 \mathrm{~g} / \mathrm{kg}$ of lignin, 15 $\mathrm{g} / \mathrm{kg}$ of kidney beans (as a lectin source), or $15 \mathrm{~g} / \mathrm{kg}$ of tannins. Total protein flow represents protein intake minus retention using the apparent ileal digestibility of the protein; ingredient-specific ileal protein flow is corrected for protein flow in pigs fed the casein diet. Each bar represents the mean of 6 pigs. ${ }^{a-c} P<0.05$.

determine endogenous protein and AA losses in pigs (Kies et al., 1986; Furuya and Kaji, 1989; Jansman et al., 2002). The true digestibility of CP and AA in casein is usually assumed to be $99 \%$, and casein effectively minimizes specific secretions of endogenous protein and AA (Kies et al., 1986; Jansman et al., 2002). We used Solkafloc (purified cellulose) to balance the diets for total cellulose, and this included some cellulose addition to our casein control diet. However, because purified cellulose does not affect endogenous protein ileal losses (de Lange et al., 1989; Furuya and Kaji, 1992; Leterme et al., 1992), the casein control diet can be used to estimate basal endogenous protein flow. Therefore, the amount, which represents minimal values, and AA composition of endogenous protein can be calculated from studies in which the AID of protein in casein has been determined (Kies et al., 1986; Furuya and Kaji, 1989; Jansman et al., 2002). Indeed, the AID values of CP and AA for the casein diet in the present experiment (Table 3) are in agreement with results reported by other researchers (Kies et al., 1986; Furuya and Kaji, 1989; Chung and Baker, 1992).

The AID of AA are usually used as the basis for calculating the supply to the body. Values for the AID and SID are primarily affected by the level of feed intake, protein intake, and diet characteristics (Souffrant et al., 1993; Sauer et al., 2000). There were no differences in feed and protein intake among the pigs fed the different diets, because these were controlled; therefore, differences in digestibilities must be due to diet characteristics. Of the indispensable AA, AID of Thr was lowest in all pigs, suggesting that endogenous AA losses were greater for Thr than for the other AA. In agreement with studies reviewed by Sauer and Ozimek (1986), these data suggest that a greater proportion of this AA is required for maintenance in the growing pig.

Sève and Hess (2000) discussed dietary conditions that influence the endogenous losses of AA and concluded that the rate of endogenous secretion was primarily dependent on the amount of protein and fiber in the diet. In the current study, ingredient-specific ileal flows of protein (i.e., corrected for flows in casein diet; Figure 1) were affected by dietary components such as dietary fiber, lectins, and condensed tannins, in agreement with studies by Jansman (1993) and Schulze et al. (1994). The length of the pretest period has been reported to affect the amount and AA composition of endogenous protein in ileal digesta of pigs (Leterme et al., 1992; Jansman et al., 1993). In the present experiment, the pigs received the diets for $12 \mathrm{~d}$ before 


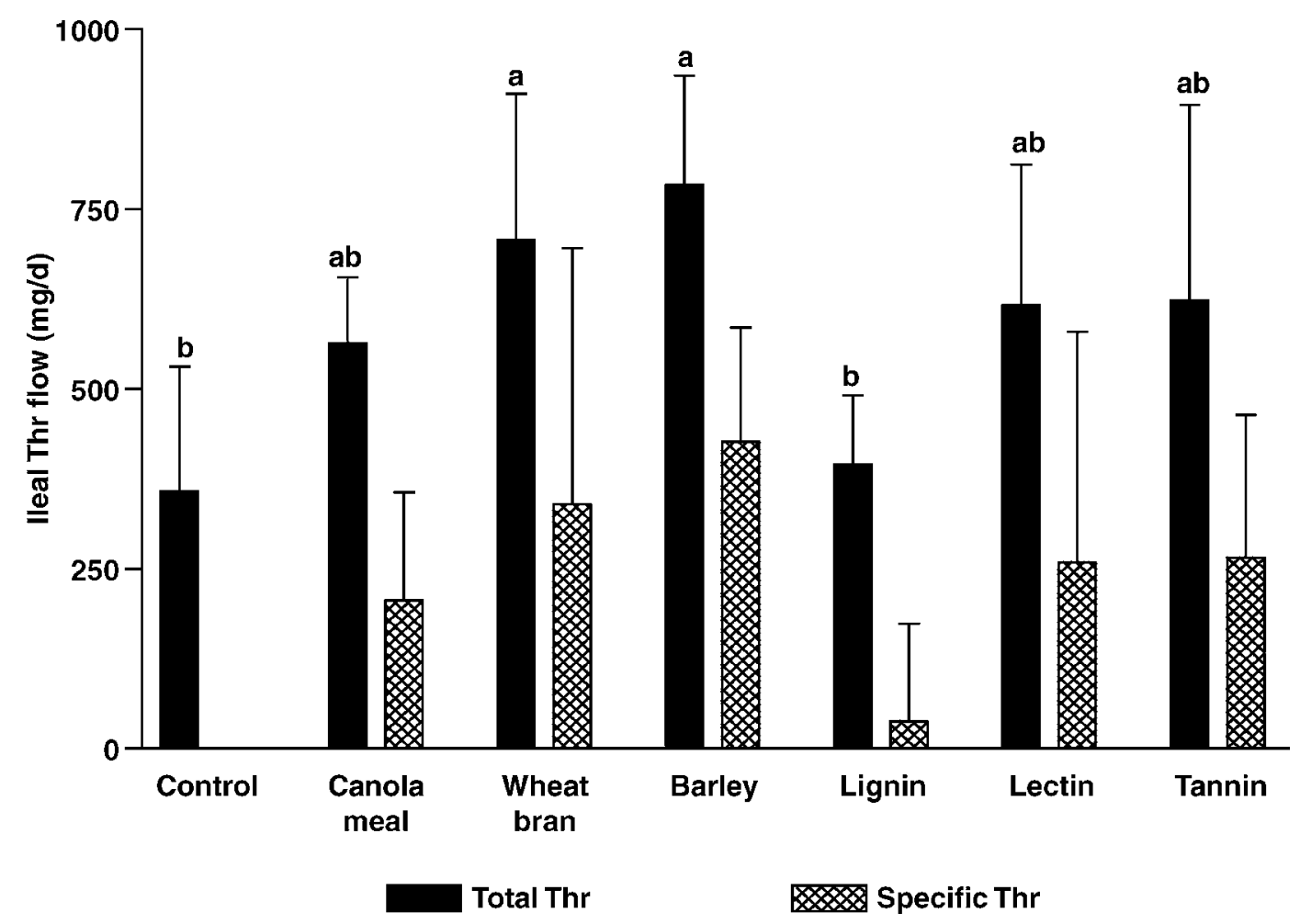

Figure 2. Total and ingredient-specific ileal Thr flow $(\mathrm{mg} / \mathrm{d})$ in growing pigs fed casein-based diets with: no supplement (control), $100 \mathrm{~g} / \mathrm{kg}$ of canola meal, $100 \mathrm{~g} / \mathrm{kg}$ of wheat bran, $150 \mathrm{~g} / \mathrm{kg}$ of barley, $22.5 \mathrm{~g} / \mathrm{kg}$ of lignin, 15 $\mathrm{g} / \mathrm{kg}$ of kidney beans (as a lectin source), or $15 \mathrm{~g} / \mathrm{kg}$ of tannins. Total Thr flow represents Thr intake minus retention using the apparent ileal digestibility of Thr; ingredient-specific ileal Thr flow is corrected for Thr flow in pigs fed the casein diet. Each bar represents the mean of 6 pigs. ${ }^{a, b} P<0.05$.

digesta collection to ensure that the time of adaptation was sufficient to elicit diet-specific responses.

Because cellulose has no effect on ileal endogenous $\mathrm{N}$ excretion in pigs (de Lange et al., 1989; Furuya and Kaji, 1992; Leterme et al., 1992), other fibrous constituents in purified NDF (i.e., hemicellulose) induce the increased endogenous $\mathrm{N}$ secretion. Indeed, pigs fed the barley (representing moderate hemicellulose) and wheat bran (high hemicellulose) diets had the lowest AID of CP, Thr, Ile, and Val (Table 3). Pigs fed these diets also tended to have the lowest AID for all indispensable AA $(P<0.08)$. The AID and ileal recoveries of AA observed suggest that wheat bran and barley increased endogenous protein and AA losses, probably including an increase in mucus secretion. Lien (1995) determined that mucin represented approximately 5 to $11 \%$ of total endogenous protein. In mucin, Thr has the largest concentration of any indispensable AA (28 to $35 \%$ of total AA), whereas its concentration in nonmucin endogenous protein is much smaller (Mantle and Allen, 1981; Lien, 1995). Indeed, the barley (moderate hemicellulose) and wheat bran (high hemicellulose) groups had greater total ileal flow of Thr compared with control (no hemicellulose) pigs (Figure 2). Thus, an increase in the rate of Thr loss, relative to other AA, at the distal ileum strongly supports the conclusion that there was an increase in mucin secretion and loss in pigs fed diets containing wheat bran and barley.
The current study showed that condensed tannins (15 g/kg) from grape reduced the AID of CP and Thr (Table 3). Similar findings were reported by Jansman et al. (1993), in piglets fed diets containing field beans with various levels ( 4 to $14 \mathrm{~g} / \mathrm{kg}$ ) of condensed tannins. Several studies (reviewed by Jansman, 1993) have also shown that tannins in different feedstuffs reduced AID of protein and AA in pigs and other animals. In particular, the inclusion of $15 \mathrm{~g} / \mathrm{kg}$ of tannins in the current study decreased AID of Thr compared with casein (Table $3,82.6$ vs. 90.6). This suggests that the reduced protein and AA digestibilities resulting from the inclusion of condensed tannins in the diet of pigs is either due to interaction of tannins with dietary proteins or due to an increase in endogenous intestinal secretions (Jansman, 1993).

Because the diet design controlled total protein, ME, cellulose, and Thr availability, AID comparisons demonstrated that wheat bran, barley, and tannins diets, at concentrations typical in swine diets, led to increased endogenous protein (except tannins) and Thr losses compared with the casein control. The SID comparisons were used to determine which of the ANF were most effective at inducing endogenous protein losses. When the control diet was used to determine SID, the data suggested that the wheat bran, barley, and tannins diets significantly induced endogenous losses of most indispensable AA (except for Thr) compared with the 


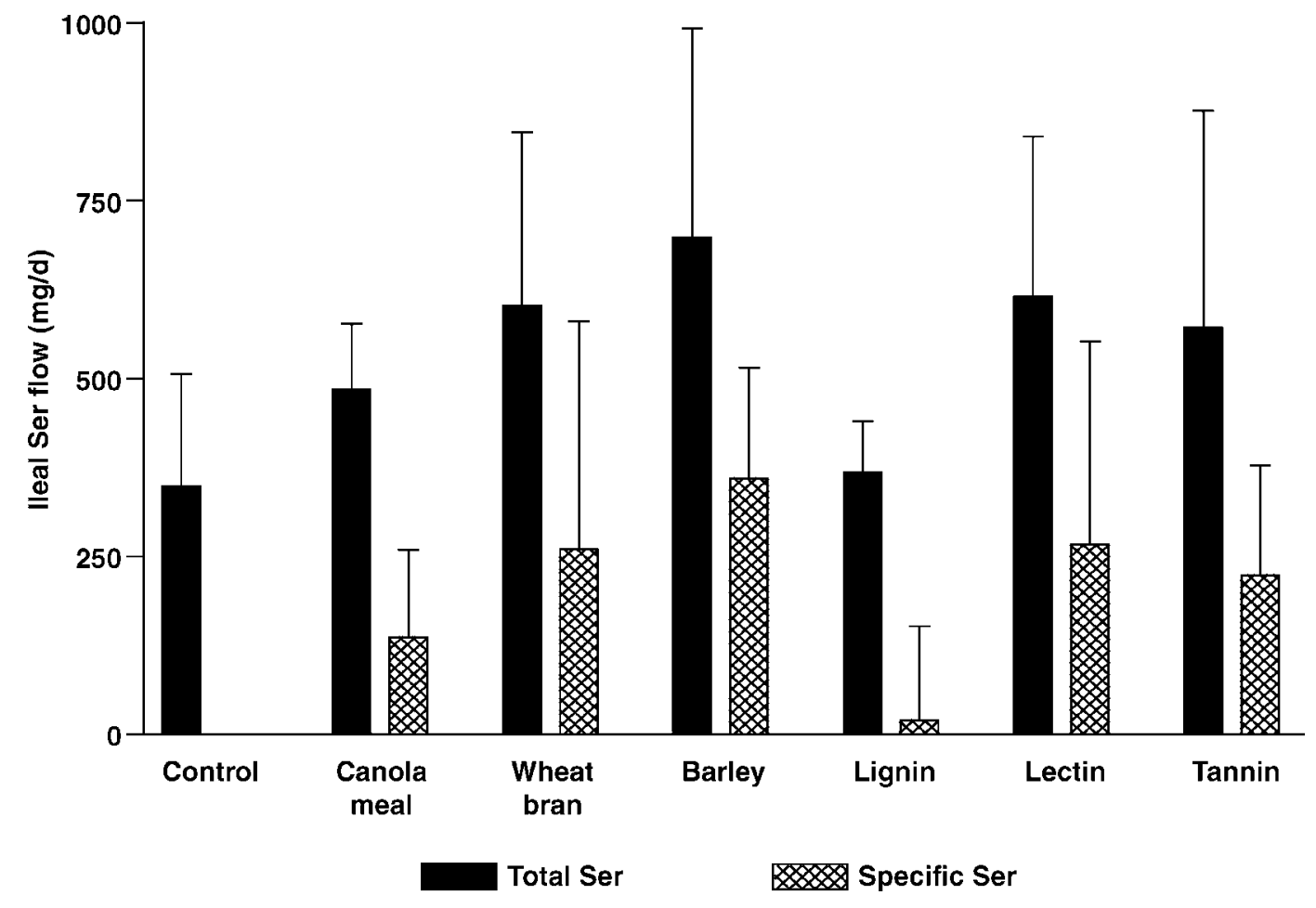

Figure 3. Total and ingredient-specific ileal Ser flow $(\mathrm{mg} / \mathrm{d})$ in growing pigs fed casein-based diets with: no supplement (control), $100 \mathrm{~g} / \mathrm{kg}$ of canola meal, $100 \mathrm{~g} / \mathrm{kg}$ of wheat bran, $150 \mathrm{~g} / \mathrm{kg}$ of barley, $22.5 \mathrm{~g} / \mathrm{kg}$ of lignin, 15 $\mathrm{g} / \mathrm{kg}$ of kidney beans (as a lectin source), or $15 \mathrm{~g} / \mathrm{kg}$ of tannins. Total Ser flow represents Ser intake minus retention using the apparent ileal digestibility of Ser; ingredient-specific ileal Ser flow is corrected for Ser flow in pigs fed the casein diet. Each bar represents the mean of 6 pigs.

other ANF. However, most importantly, SID of Thr was lowest of all indispensable AA among ANF groups, suggesting that each of the ANF induced some endogenous Thr losses over control. In particular, the disproportionate loss of Thr suggests that Thr-rich proteins dominated endogenous protein losses.

Pigs receiving the wheat bran (high hemicellulose) and the barley (moderate hemicellulose) diets had lower percentage retention of absorbed $\mathrm{N}$ than the other pigs (Table 5), indicating that the greater endogenous losses impacted performance. This lower $\mathrm{N}$ retention is probably a result of the greater endogenous protein losses, which would reduce whole-body protein retention and deposition. Souffrant et al. (1993) and Krawielitzki et al. (1994) showed that approximately $25 \%$ of the total endogenous protein secretions are present in the ileal digesta of pigs. The endogenous $\mathrm{N}$ supply is then replenished at the expense of AA for growth (Fuller and Reeds, 1998). Indeed, in spite of similar feed intakes, pigs fed wheat bran and barley diets had lower BW gains in the second week (results not shown). Despite the slightly lower BW gains for the pigs fed wheat bran- and barleybased diets, there were no differences in G:F among pigs fed the various diets. Although we only used 6 pigs per treatment, our limited interpretation of these performance data is that because of the greater ileal

Table 5. Nitrogen balance in growing pigs fed diets containing common levels of antinutritional factors ${ }^{1}$

\begin{tabular}{|c|c|c|c|c|c|c|c|c|c|}
\hline Item & Control & $\begin{array}{c}\text { Canola } \\
\text { meal }\end{array}$ & $\begin{array}{l}\text { Wheat } \\
\text { bran }\end{array}$ & Barley & Lignin & Lectin & Tannins & SD & $\begin{array}{c}P- \\
\text { value }\end{array}$ \\
\hline N Intake, g/d & 22.5 & 22.49 & 19.47 & 21.83 & 21.88 & 22.34 & 22.35 & 2.52 & 0.28 \\
\hline Absorbed N, g/d & 19.68 & 18.97 & 15.21 & 18.44 & 18.62 & 17.86 & 19.17 & 3.40 & 0.40 \\
\hline Urinary $\mathrm{N}, \mathrm{g} / \mathrm{d}$ & 5.31 & 5.49 & 5.50 & 6.12 & 5.55 & 5.41 & 4.91 & 0.85 & 0.32 \\
\hline $\mathrm{N}$ retention, $\mathrm{g} / \mathrm{d}$ & 14.38 & 13.49 & 9.71 & 12.29 & 13.07 & 12.45 & 14.26 & 2.93 & 0.16 \\
\hline
\end{tabular}

${ }^{\mathrm{a}, \mathrm{b}}$ Values with different superscripts within the same row are different at $P<0.05 ; \mathrm{n}=6$ per dietary treatment.

${ }^{1}$ All diets were casein-based with: no supplement (control), $100 \mathrm{~g} / \mathrm{kg}$ of canola meal, $100 \mathrm{~g} / \mathrm{kg}$ of wheat bran, $150 \mathrm{~g} / \mathrm{kg}$ of barley, $22.5 \mathrm{~g} / \mathrm{kg}$ of lignin, $15 \mathrm{~g} / \mathrm{kg}$ of kidney beans (as a lectin source), or $15 \mathrm{~g} / \mathrm{kg}$ of tannins. 
nutrient flow and AID of AA, the maintenance demand for AA, particularly Thr for mucin synthesis, was greater in the pigs fed the barley and the wheat bran diets such that there was less AA available for lean tissue protein deposition, resulting in a lower retention of absorbed $\mathrm{N}$ and lower BW gain.

Because the pattern of AA required for maintenance is different from that required for growth (NRC, 1998), replenishing endogenous AA losses will alter the pattern of AA available for protein deposition. This shift in AA pattern may, in turn, result in an increase in urinary N excretion (Sève and Henry, 1996). Thus, an increase in endogenous mucin losses would result in less AA such as Thr, Ser, and Pro being available for $\mathrm{N}$ retention. If any indispensable AA, such as Thr, becomes limiting, then other AA would be in excess, resulting in greater urinary $\mathrm{N}$ losses. Indeed, the wheat bran and barley groups excreted more urinary $\mathrm{N}$ as a percentage of absorbed $\mathrm{N}$ supporting such a mechanism. The combination of greater endogenous losses of $\mathrm{N}$ at the ileum and via urine would lead to lower $\mathrm{N}$ retention and lower growth.

In conclusion, these results show that the barleybased diet (representing moderate hemicellulose) lowered the ileal Thr and protein digestibility by 12 and $8 \%$, respectively, compared with the casein diet. Wheat bran (high hemicellulose) diet had the next lowest ileal Thr digestibility, $11 \%$ lower than in pigs fed the casein, whereas protein digestibility was $10 \%$ lower than in casein. Pigs receiving the wheat bran and the barley diets had the lowest $\mathrm{N}$ retentions of all, except for the lignin diet. High-fiber ingredients, primarily hemicellulose content such as in wheat bran and barley, significantly decreased the apparent and true ileal protein and AA digestibilities; Thr was particularly affected. The various antinutritive factors, at concentrations typical in feedstuffs, are known mucin secretagogues and may have stimulated mucus secretion and hence increased endogenous AA losses. Therefore, the values used by NRC (1998) to correct AID values to true ileal digestibility values are not applicable to all ingredients. New values for endogenous losses, particularly for Thr, are required for ingredients containing different levels of antinutritional factors, particularly fiber.

\section{LITERATURE CITED}

Allen, A., D. A. Hutton, J. P. Pearson, and L. A. Sellers. 1984. Mucus glycoprotein, structure, gel formation and gastrointestinal mucus function. Page 137 in Mucus and Mucosa. Ciba Found. Symp. 109. Pitman, London, UK.

AOAC. 1995. Official Methods of Analysis. 16th ed. Assoc. Off. Anal. Chem., Washington, DC.

Bertolo, R. F. P., C. Z. L. Chen, G. Law, P. B. Pencharz, and R. O. Ball. 1998. Threonine requirement of neonatal piglets receiving total parenteral nutrition is considerably lower than that of piglets receiving an identical diet intragastrically. J. Nutr. 128:1752-1759.

Bond, D. A., and C. B. Smith. 1989. Possibilities for the reduction of antinutritional factors in grain legumes by breeding. Pages $285-$ 296 in Recent Advances in Research on Antinutritional Factors in Legume Seeds. J. Huisman, A. F. B. van der Poel, and I. E. Liener, ed. Pudoc, Wageningen, the Netherlands.

Bradstreet, R. 1965. The Kjeldahl Method of Organic Nitrogen. Acad. Press, New York, NY.

Bravo, L. 1998. Polyphenols: Chemistry, dietary sources, metabolism and nutritional significance. Nutr. Rev. 56:317-333.

Butts, C. A., P. J. Moughan, W. C. Smith, and D. H. Carr. 1993. Endogenous lysine and other amino acid flows at the terminal ileum of the growing pig ( $20 \mathrm{~kg}$ bodyweight): The effect of proteinfree, synthetic amino acid, peptide and protein alimentation. J. Sci. Food Agric. 61:31-40.

Chiou, P. W. S., B. Yu, and C. Lin. 1994. Effect of different components of dietary fiber on the intestinal morphology of domestic rabbits. Comp. Biochem. Physiol. Comp. Physiol. 108:629-638.

Chung, T. K., and D. H. Baker. 1992. Apparent and true amino acid digestibility of a crystalline amino acid mixture and of casein: Comparison of values obtained with ileal-cannulated pigs and cecectomized cockerels. J. Anim. Sci. 70:3781-3790.

de Lange, C. F. M., W. C. Sauer, R. Mosenthin, and W. B. Souffrant. 1989. The effect of feeding different protein-free diets on the recovery and amino acid composition of endogenous protein collected from the distal ileum and feces in pigs. J. Anim. Sci. 67:746-754.

Fenton, T. W., and M. Fenton. 1979. An improved procedure for the determination of chromic oxide in feed and feces. Can. J. Anim. Sci. 59:631-634.

Fuller, M. F., and P. J. Reeds. 1998. Nitrogen cycling in the gut. Annu. Rev. Nutr. 18:385-411.

Furuya, S., and Y. Kaji. 1989. Estimation of the true ileal digestibility of amino acids and nitrogen from their apparent values for growing pigs. Anim. Feed Sci. Technol. 26:271-285.

Furuya, S., and Y. Kaji. 1992. The effects of feed intake and purified cellulose on the endogenous ileal amino acid flow in growing pigs. Br. J. Nutr. 68:463-472.

Huisman, J., and G. H. Tolman. 1992. Anti-nutritional factors in the plant proteins of diets for non-ruminants. Pages 3-31 in Recent Advances in Animal Nutrition. P. C. Garnsworthy, W. Haresign, and D. J. A. Cole, ed. Butterworth-Heinemann Ltd., Oxford, UK.

Jansman, A. J. M. 1993. Tannins in feedstuffs for simple stomached animals. Nutr. Res. Rev. 6:209-236.

Jansman, A. J. M., J. Huisman, and A. F. B. van der Poel. 1993. Ileal and feacal digestibility in piglets of field beans (Vivia faba L.) varying in tannin content. Anim. Feed Sci. Technol. 42:83-96.

Jansman, A. J. M., W. Smink, P. van Leeuwen, and M. Rademacher. 2002. Evaluation through literature data of the amount and amino acid composition of basal endogenous crude protein at the terminal ileum of pigs. Anim. Feed Sci. Technol. 98:49-60.

Kies, A. K., P. J. Moughan, and W. C. Smith. 1986. The apparent and true ileal digestibility of nitrogen and amino acids in lactic casein for the growing pig. Anim. Feed Sci. Technol. 16:169-178.

Krawielitzki, K., F. Kreienbring, T. Zebrowska, R. Schadereit, and J. Kowalczyk. 1994. Estimation of $\mathrm{N}$ absorption, secretion and reabsorption in different intestinal sections of growing pigs using the 15N-dilution method. Pages 79-82 in Proc. VIth Int. Symp. Dig. Physiol. Pigs 1994. W. B. Souffrant and H. Hagemeister, eds. EAAP Publ. 80. Eur. Assoc. Anim. Prod., Dummerstorf, Germany,

Lamont, J. T. 1992. Mucus: The frontline of intestinal mucosal defense. Ann. N. Y. Acad. Sci. 664:190-201.

Leterme, P., L. Pirard, and A. Thewis. 1992. A note on the effect of wood cellulose level in protein-free diets on the recovery and amino acid composition of endogenous protein collected from the ileum in pigs. Anim. Prod. 54:163-165.

Li, S., W. C. Sauer, and M. Z. Fan. 1993. The effect of dietary crude protein level on ileal and fecal amino acid digestibility in early weaned pigs. J. Anim. Physiol. Anim. Nutr. (Berl.) 70:117-128.

Lien, K. A. 1995. Endogenous protein in ileal digesta: Estimation of the mucin content and evaluation of the $15 \mathrm{~N}$-isotope dilution technique. PhD Diss. Univ. Alberta, Edmonton, Alberta, Canada. 
Llames, C. R., and J. Fontaine. 1994. Determination of amino acids in feeds: Collaborative study. J. AOAC Int. 77:1362-1402.

Low, A. G. 1980. Nutrient absorption in pigs. J. Sci. Food Agric. 31:1087-1130.

Mantle, M., and A. Allen. 1981. Isolation and characterization of the native glycoprotein from pig small intestine mucus. Biochem. J. 195:267-275.

May, R. W., and J. M. Bell. 1971. Digestible and metabolizable energy values of some feeds for the growing pig. Can. J. Anim. Sci. 51:271-278.

Moehn, S., R. F. Bertolo, P. B. Pencharz, and R. O. Ball. 2005. Development of the indicator amino acid oxidation technique to determine the availability of amino acids from dietary protein in pigs. J. Nutr. 135:2866-2870.

Moughan, P. J. 2003. Amino acid digestibility and availability in foods and feedstuffs. Proc. 9th Int. Symp. Dig. Physiol. Pigs. Volume 1:199-221. R. O. Ball, ed. University of Alberta, Edmonton, Alberta, Canada.

Moughan, P. J., and S. Rutherford. 1990. Guanidination of lysine in selected dietary proteins. J. Agric. Food Chem. 38:209-211.

Moughan, P. J., and G. Schuttert. 1991. Composition of nitrogencontaining fractions in digesta from the distal ileum of pigs fed a protein-free diet. J. Nutr. 121:1570-1574.

Nachbar, M. S., and J. D. Oppenheim. 1980. Lectins in the United States diet: A survey of lectins in commonly consumed foods and a review of the literature. Am. J. Clin. Nutr. 33:2338-2345.

Noblet, J., H. Fortune, S. Dubois, and Y. Henry. 1989. Nouvelles bases d'estimations des teneurs en energie digestible, metabolisable et nette des aliments pour le porc. Inst. Natl. Rech. Agron., Paris, France.

Noblet, J., and J. M. Perez. 1993. Prediction of digestibility of nutrients and energy values of pig diets from chemical analysis. J. Anim. Sci. 71:3389-3398.

NRC. 1998. Nutrient Requirements of Swine. 10th rev. ed. Natl. Acad. Press, Washington, DC.

Pusztai, A., T. P. King, and E. M. W. Clarke. 1982. Recent advances in the study of the nutritional toxicity of kidney bean (Phaseolus vulgaris) lectins in rats. Toxicon 20:195-197.

Satchithanandam, S., M. Vargofcccak-Apker, R. J. Calvert, A. R. Leeds, and M. M. Cassidy. 1990. Alteration of gastrointestinal mucin by fiber feeding in rats. J. Nutr. 120:1179-1184.

Sauer, W. C. 1976. Factors influencing amino acid availabilities for cereal grains and their components for growing monogastric animals. PhD Diss. Univ. Manitoba, Winnipeg, Manitoba, Canada.
Sauer, W. C., M. Z. Fan, R. Mosenthin, and W. Drochner. 2000. Methods for measuring ileal amino acid digestibility in pigs. Pages 279-306 in Farm Animal Metabolism and Nutrition: Critical Reviews. J. P. F. DiMello, ed. CAB Int., Wallingford, Oxon, UK.

Sauer, W. C., J. He, M. Z. Fan, M. Cervantes, A. Kies, and W. Caine. 2001. Variability of amino acid digestibility in pigs: Inherent factors in feedstuffs and considerations in methodology. J. Anim. Feed Sci. 10(Suppl.1):115-138.

Sauer, W. C., and L. Ozimek. 1986. Digestibility of amino acid in swine: Results and their practical applications. A review. Livest. Prod. Sci. 15:367-388.

Schulze, H., P. Van Leeuwen, M. W. A. Verstegen, J. Huisman, W. B. Souffrant, and F. Ahrens. 1994. Effect of level of dietary neutral detergent fiber on ileal apparent digestibility and ileal nitrogen losses in pigs. J. Anim. Sci. 72:2362-2368.

Sedgwick, G. W., T. W. Fenton, and J. R. Thompson. 1991. Effect of protein precipitating agents on the recovery of plasma free amino acids. Can. J. Anim. Sci. 71:953-957.

Sève, B., and Y. Henry. 1996. Protein utilization in non ruminants. Pages 59-82 in Proc. VII Symp. Protein Metab. Nutr., Santarém, Portugal. A. F. Nunes, A. V. Portugal, J. P. Costa, and J. R. Ribeiro, ed. EAAP. Publ. No. 81, Estacao Zootecnica Nacional (EZN), Agrária, Portugal. Estaçao Zootécnica Nacional. EAAP Publication 81.

Sève, B., and V. Hess. 2000. Amino acid digestibility in formulation of diets for pigs: Present interest and limitations, future prospects. Page 167 in Recent Advances in Animal Nutrition 2000. P. C. Garnsworthy and F. Wiseman, ed. Nottingham Univ. Press, Nottingham, UK.

Shah, N., M. T. Atallah, R. R. Mahoney, and P. L. Pellett. 1982. Effect of dietary fiber components on fecal nitrogen excretion and protein utilization in growing rats. J. Nutr. 112:658-666.

Smiricky, M. R., C. M. Grieshop, D. M. Albin, J. E. Wubben, V. M. Gabert, and G. C. Fahey Jr. 2002. The influence of soy oligosaccharides on apparent and true ileal amino acid digestibilities and fecal consistency in growing pigs. J. Anim. Sci. 80:2433-2441.

Souffrant, W. B., A. Rerat, J. P. Laplace, B. Darcy-Vrillon, R. Kohler, T. Corring, and G. Gebhardt. 1993. Exogenous and endogenous contributions to nitrogen fluxes in the digestive tract of pigs fed a casein diet. III. Recycling of endogenous nitrogen. Reprod. Nutr. Dev. 33:373-382.

Sweeney, R. A., and P. R. Rexroad. 1987. Comparison of LECO FP-228 "Nitrogen determinator" with AOAC copper catalyst Kjeldahl method for crude protein. J. Assoc. Off. Anal. Chem. 70:10281030 . 